\author{
Łukasz Dekier \\ Poznan University of Economics \\ al. Niepodlegtości 10, 61 - 875 Poznań \\ e-mail:klit@ue.poznan.pl \\ tel: 618543531 \\ fax: 618543530 \\ lukas.dekier@ue.poznan.pl
}

\begin{abstract}
In 2008 the worldwide economic crisis grew in strength and many companies from different walks of life commenced to seek the opportunity to enhance their economic situation. The outcomes of the effort resulted in the implementation of modern management methods, such as Six Sigma, Theory of Constraints, TQM or Lean Management. Due to its high efficacy the last one turned most preferred. The aim of this paper is to give an account of the origins and evolution of Lean Management. The brief history of Toyota Production System (TPS) will be outlined alongside its most essential instruments: jidoka, Just-in-time and "pull-flow production". Additionally, the functioning of companies exercising Lean Management as a direct successor of TPS will be demonstrated. Eventually, the underlying rules of Lean Management with their applications will be put forward to elicit its assets and discern the differences between Lean Management and the former systems.
\end{abstract} May, 2012

Keywords: Lean Management, Lean Manufacturing, Toyota Production System, Lean Leadership.

JEL Classification: M 11.

\title{
INTRODUCTION
}

One of the paramount objectives of a company is to generate the highest profits via gaining new markets or taking over other companies (Bratnicki M., Krupski R., 2002, translation mine, ŁD). This practice known as the Strategy of Merging and Acquisition is by many managers considered an effective one. However, the experiences of the latest worldwide economic crisis have definitely changed their viewpoints. Some of the companies exercising such strategies were not capable of remaining on the market even though they accepted governmental grants, not to mention the companies' vast capital reserves which they possessed individually (http://www.tvn24.pl, 2010, translation mine, ŁD). There are selected groups of companies 
that have hardly experienced the collapse in the market. They are all linked with a modern approach of management. The groups include:

- Lean Management

- Six Sigma

- Theory Of Constraints

- TQM

The aforementioned approaches of management are becoming increasingly popular (Maciejec L., 2003, translation mine, $\mathrm{ED}$ ). Owing to its efficacy, Lean Management is in the limelight. The aim of this paper is to give an account of the evolution and intricacies of the approach.

\section{TOYOTA PRODUCTION SYSTEM}

The roots of Lean can be found in the Japanese company of Toyota. The origins of Toyota Production System date back to the beginnings of the twentieth century. The fathers of the system was Sakichi Toyoda, his sons: Kiichiro Toyoda and Eiji Toyoda as well as Taiichi Ohno, a manufacturing engineer. Sakichi Toyoda, who then worked in textile industry, invented a motor-driven loom with a specialized mechanism devised to stop in case of breaking off the thread. The mechanism became later a foundation for Jidoka (automatization with human manufacturing), one of the two main pillars on which Toyota Production System was built. Due to the application of a fault detection sensor, the defects stemming from human-related imperfections were reduced and the production capacity was elevated.

In 1910, Sakichi Toyoda "visited the United States for the first time and realized that the new automotive era just was beginning” (Ohno T., 2008, translation mine, ŁD). Yet, the Toyoda family needed 20 years to materialize their plans. In 1929 Kiichiro Toyoda arrived in the USA with the aim of scrutinizing the local companies in the automotive industry. He was particularly fascinated with the Ford production system, which in 1913 introduced the serial production of its automobile (the T model) (Kornicki L., Kubik S., 2008, translation mine, ŁD). Consequently, when Toyota Motor Company initiated their production, Kiichiro decided to implement some of the resolutions he had witnessed in the USA. The then Japan suffered from reduced demand, therefore diverse automobiles were necessarily produced in smaller numbers on the same assembly lines. In order to compete in the mass production automotive industry, which had already been introduced in European and American companies, Toyota was forced to change the methods of production. Kiichiro Toyoda fully understood the fact that it was mandatory to create a fast and flexible process of production as a result of which the clients would obtain desired, high-quality and reasonably-priced automobiles. Kiichiro commenced preparatory work to produce in the Just-in-time system. The objective of the latter was to elevate the production capacity and reduce waste painstakingly.

In the 1950s Sakichi's son, Eiji Toyoda, visited the Ford company. It seems that owing to the visit Toyoda together with Taiichi Ohno were capable of creating a system linking the two pillars of the TPS (Jidoka and Just-in-time) with the Ford assembly line.

Shortly after the previous improvement Taiichi Ohno advanced another concept called "pull-flow production", an old practice in American supermarkets. The pull-flow production allowed to generate as many products as could be exploited in the successive process. In turn, it would facilitate the reduction of overproduction.

The Toyota Production System did not arouse interest in Japanese and American companies by 1973. Not until the production had to be reduced, were Japanese and American managers capable of noticing significant outcomes that Toyota had achieved (Graczkowski S., 2008, translations mine, ŁD). 
As a result, a great interest was taken in the system (Liker J.K., 2004, Ohno T., 2008 and Lisiński M., Ostrowski B., 2006, translations mine, ŁD).

\section{LEAN MANUFACTURING}

Lean Manufacturing was coined in 1991 by James P. Womack, Daniel T. Jones and Daniel Roos from The Massachussets Institute of Technology in their book The Machine That Changed the World, in which they compared Japanese and American companies. The most efficient turned Toyota Motor Company with its Toyota Production System (TPS). The TPS was hailed the first system working in accordance with the guidelines of Lean. In 2001, James P. Womack and Daniel T. Jones published

"Lean Thinking: Banish Waste and Create Wealth in Your Corporation”, in which they precisely defined the foundations of the Lean Philosophy (Cholewicka-Goździk K, 2001, translation mine, ŁD).

Lean Manufacturing is regarded as a successor of the TPS. It applies the instruments developed formerly by Toyota. Additionally, five principles have been added to establish the patterns for the company's better functioning.

\section{Determining the product's value in the eyes of clients}

This principle suggests a company should accurately determine the product's value in the eyes of clients. The best example would be airlines. When a passenger aims to reach a destination, s/he is merely preoccupied with being transported from A to B, thus the plane itself is of highest value to the passenger. However, the passenger is obliged to stand in a line for registering the baggage or for a passport check. Therefore, airlines should do everything in their power to make the percentage share of the flight's value the highest in terms of the passenger's general participation in the excursion (on condition that the length of the flight remains the same).

\section{Identifying and clarifying the value stream for the product}

The second principle advises to carefully identify the processes the product undergoes from the very beginning of the production stage up to delivering the product to the client. Simultaneously, the value is contributed to particular stages of the product's development. It is essential to demonstrate the values stream via designing a so-called value stream map (Rother M., Shook J., 1999).

\section{Providing the fast and undisturbed value stream}

The third principle concentrates on eliminating the factors that inhibit the production process and prolong the client's awaiting time from the value stream. These factors are defined as waste (Japanese Muda). They have precisely been characterized by Taiichi Ohno in his book "Toyota Production System"

\section{Allowing clients to elicit the value from the producer}

The fourth principle states that the company should commence to generate the product on the client's demand. Implementing such a resolution is not simple. However, there are branches i.e. the automotive that perform well in the matter.

\section{Striving for excellence}

The final principle advocates a constant improvement of the value stream. It was best captured in the classic statement by Henry Ford:

"Companies that grow owing to development

and improvements, will not perish.

But when the company stops being creative 
and believes that it has accomplished excellence

and only has to persist in producing - it is finished"

(own translation)

It is important to note that Lean Manufacturing is essentially adjusted towards production processes. This method does not pay much attention to the aspects of human resources management. That is the main difference between Lean Manufacturing and its successor Lean Management.

\section{LEAN MANAGEMENT}

Lean Management is a method of managing companies that assumes adaptation to the actual market conditions via organizational and functional alternations. The heart of Lean Management is the act of "polishing up" the company thanks to changes in its policy, particularly in the company's assets and its management styles. Additionally Lean Management concentrates on professional training and shaping the staffs attitudes as well as maintaining positive public relation (Lichtarski J., 1997, translation mine, ŁD).

This method pays vital attention to the aspects concerning human resources management in the company. The author of this paper has collected and briefly defined selected constituents that every manager should give thought to. They are the following:

Good atmosphere in the workplace - it is incumbent upon the employer to build up a positive atmosphere in the company. A positive atmosphere does not only help the employees accomplish their daily tasks, but also cements bonds between co-workers and the company. As a result, the employees are motivated enough to professional dedication, i.e. when they have to work overtime in order to fulfil the commissioned task.

Setting the objectives - in order for a person to work effectively, s/he has to know the goals of the work. Thus, it is of significant importance to set both long-term and short-term objectives for the employees. The former would concern the advancement of their professional career. The latter would focus on paying attention to the daily tasks they perform. This constituent of Lean Management is illustrated with a transparently determined career path that indicates the employee what tasks have to be accomplished and what has to be learnt if one is to be considered for a potential promotion

Communication - it is one of the most principal elements that is frequently omitted in human resources management. Basically, managers of all levels should construct a system of information exchange among the employees of a particular department. It is worthwhile to organize daily brief meetings for employees to elevate the quality of communication. At the meeting the employees could exchange information, check the status of tasks or solve problems on a regular basis.

Proper motivation - Lean Management is one of the management styles that advises managers to lay to rest traditional methods of motivation which consist in a bonus system, so-called "carrot-and-stick" approach (Blikle A., 2011, translation mine, $€ D$ ). Which results in merely short-term outcomes, whereas managers ought to seek internal motivators for individual employees.

Wasting human potential - many companies pursuit the aim of constant enhancement of their processes. Varied methods are undertaken to achieve this state. Occasionally, external companies are employed to improve the functioning of the target company. Sometimes, managers impose some obligations without consulting their employees. Theses types of proceedings are regarded as waste (Liker J. K., Meier D. P., 2008 , translation mine, $€ D$ ). It is recommended in modern companies to consult alterations with the employees who have the direct picture of the problem they have to deal with on a regular basis. A very 
functional instrument is a "suggestion system" (Masaaki, I., 2006, translation mine, ŁD) that allows to use the input from the company's employees.

Development of employees - one of the most essential resources in the majority of companies are both indirect and production-support employees. For that reason, managers ought to do what is in their power to provide the employees with the opportunities of self-development. It is frequently belittled or simply forgotten that investing in human resources equals investing in the company and that the outcomes will soon turn beneficial. There are selected methods that contribute to the aim of having highly-qualified management. The most recognizable ones are: the development projects and the competence matrix.

Leadership - managers ought to be constantly conscious of the importance of the management style they apply to their employees. It is categorically unacceptable for managers to claim credit for the actions of their employees or not use materials the subordinates have been made to prepare. It is additionally vital for the managers to seek resolutions of problems rather than victims when crisis situations crop up. The managers are obliged to improve their soft skills in order to become the Lean Leaders and consequently inspire respect among the employees.

\section{SUMMARY}

Lean Management is a successor of both Toyota Production System and Lean Manufacturing. It is currently considered one of the most popular management systems in the world. Its efficacy has been repeatedly proven and defined by many recognizable scientists and practitioners (Womac J.P., Jones D.T., 2008 translation mine, $\mathrm{LD}$ ). The question arises whether the system whose origins date back to the beginnings of the twentieth century is capable of satisfying the requirements of the contemporary economy. It surely is. One of the underlying rules of Lean Management is constant striving for excellence owing to which the system continually evolves. We are already witnessing the emergence of the Lean Sigma that is a synthesis of Lean Management and Six Sigma (Eckes G., 2010, translation mine, ŁD) or of the TSL. The latter is a combination of the two aforementioned approaches and additionally of the Theory of Constraints. Hence, the author predicts that the system that has been under analysis in this paper will endure for many years as one of the best management traditions.

\section{BIBLIOGRAPHY}

Blikle, A. (2011), Doktryna Jakości.

Bratnicki M., Krupski R. (2002), Zarządzanie strategiczne, WWSZiP, Poznań, s.54.

Cholewicka-Goździk, K, Metoda LEAN - doskonalenie procesów i produktów: wokót książki Jamesa P. Womack’a i Daniela T. Jones'a, Problemy Jakości, 1/2001.

Eckes, G. (2010), Rewolucja Six Sigma, MT Biznes, Warszawa.

Graczkowski, S., Total Quality Management, Reengineering i Lean Management oraz ich rozwój wobec trendów globalizacyjnych, Logistyka, 2/2008.

Kornicki, L., Kubik, S., Henry Ford-pionier standaryzacji procesów i eliminacji marnotrawstwa. Geniusz czy szaleniec?, Zarządzanie jakością, 3/2008.

Lichtarski, J. (199), Podstawy nauki o przedsiębiorstwie, WAE, Wrocław, s. 224.

Liker, J.K. (2004), Droga Toyoty, MT Biznes, Warszawa.

Liker, J.K., Meier, D. P. (2008), Toyota Talent, MT Biznes, Warszawa.

Lisiński, M., Ostrowski, B. (2006), Lean Management w restrukturyzacji przedsiębiorstwa, Antykwa, Kraków. 
Rother, M., Shook J. (1999), Naucz się widzieć, The Lean Enterprise Institute, USA.

Maciejec, L., Organizacja szczupta, efekty rozlegte, CEO, 5/2003.

Masaaki, I. (2006), Gemba Kaizen, MT Biznes, Warszawa.

Ohno T. (2008), System Produkcyjny Toyoty, Prodpress.com, Wrocław, s.93.

Womac, J.P., Jones, D.T. (2008), Lean thinking-szczupte myślenie, ProdPress.com, Wroclaw.

\section{WWW}

http://www.tvn24.pl/-1,1572251,0,1, general-motors-na-krawedzi-bankructwa,w.html z 24.04.2010 